\title{
Social Capital and Education: Implications for Student and School Performance
}

\section{Gregory K. Plagens}

Scholars seeking to understand why some students and schools perform better than others have suggested that social capital might be part of the explanation. Social capital in today's terms is argued to be an intangible resource that emerges-or fails to emerge-from social relations and social structure. Use of the term in this sense has been traced to John Dewey's writings in 1900 in The Elementary School Record. The idea that outcomes in education are conditioned by social interactions has intuitive appeal. Schools are more than learning factories where inputs are used to generate outputs; they are fundamentally social environments. Empirical evidence links social capital to higher student and school performance, but explanations of how and why the concept works as it does are varied and often vague. This article examines social capital as a concept and its link to student and school performance.

The language of social capital includes concepts that have been in use for decades. At different times social capital has been said to be about networks, associations, volunteering, trust, solidarity, sympathy, cooperation, reciprocity, belonging, norms, and relationships. Variety in the construct and its connection to many outcomes has some concerned that social capital is on its way to becoming all things to all people (Woolcock 1998) or that it has taken on a "circus-tent quality" (De Souza Briggs 1997). Despite variation in its use and roots reaching into education, economics, sociology and political science, there is some agreement about the basis for the concept. Its discovery, disappearance, and rediscovery, as well as the debate over its composition, make for an interesting story that today's educators may find valuable as they strive to address concerns about student and school performance.

\section{Social Capital: Early References}

As one might expect from a concept incorporating the word capital, social capital's first known use is in economics. James Farr (2004) traced its first appearances to 
political economists Karl Marx (1867), Henry Sidgwick (1883), John Bates Clark (1885), Edward Bellamy (1897) and Alfred Marshall (1890). Sidgwick is quoted as writing about "capital from the social point of view" (130) when contrasting capital of individuals with that of the political community. Personal holdings or trade investments belonging to individuals were perceived differently from the "aggregate of tools, inventions, improvements in land" that were jointly held (Farr 2004, 22). Much of what was viewed as social capital by the nineteenth-century political economists, such as roads and bridges, is thought of today as physical capital.

Dewey's ideas about social capital emerged with his observations of economic and social changes occurring in America. Pastoral life was beginning its passage into history when Dewey began writing in the late nineteenth and early twentieth century. The traditional means by which families earned a living out of their households, and as a result passed along information about production within the household, were being replaced by the industrial process. He described this evolution and, more importantly, reflected on the resulting role for schools in his 1899 pamphlet The School and Society (which was later included in the book of the same name in 1900). Community life was deviating from its historical course and Dewey recognized many of the important implications of this change.

The seedbed of modern social capital theory is argued to reside with Dewey (Farr 2004), whose early ideas about the importance of individuals associating with one another led him to use the term social capital in 1900 when explaining the importance of reading, writing, and arithmetic to the social life of the student: "These subjects are social in a double sense. They represent the tools which society has evolved in the past as the instruments of its intellectual pursuits. They [also] represent the keys which will unlock to the child the wealth of social capital which lies beyond the possible range of his limited individual experience" (9: 230). Dewey's ideas are reminiscent of Alexis de Tocqueville, who never discussed social capital by name but recognized the importance of social relations in American communities and the dangers imposed by the absence of associational life (1840). Tocqueville envisioned a day when the individual would be unable to produce the commonest necessities of life without the collaboration of others: "If men are to remain civilized or to become so, the art of associating together must grow and improve in the same ratio in which equality of conditions is increased" (110).

Dewey does not expound on his reference to social capital, but reading within the context there are clues to what he may have been thinking when he wrote about it. The first reference appeared in the last of nine monographs describing the application of the relatively new field of psychology to education. Dewey based his observations on experiences with an elementary school being run at that time under his direction at the University of Chicago. He was interested in the learning process and how best to instruct children so that they would be successful in solving problems, or as he described it, "adapting means to ends, even in the face of great hazard and obstacle" $(1900,228)$. Dewey is known for advocating active or experiential learning, whereby the academic lessons of the day are embedded in activi- 
ties that replicate real life problems so as to motivate children to solve them. The problems of the day were changing dramatically as Dewey began his career, and as he saw it, the emerging challenge for educators was to link academic pursuits to life in the urban and industrial setting in the same way that they had been linked to economic activity in the home. Absent this connection, books would lose their luster as valuable resources for solving problems and would be ignored, thus leaving the individual less able to adapt his means to achieve desired ends.

The new emerging industrial order would require more of individuals socially, since life in cities and work in plants was replacing life and work with the household on the family farm. In this context, Dewey's idea about basic skills being social in a double sense is an important observation. Anyone who fails to effectively make meaningful and convey the "symbols of language, including those of quantity" $(1900,230)$ would be limited in his ability to connect and collaborate with others in society. Such an individual would be left to draw on his own experiences and devices when seeking to solve crucial problems, and this might not be sufficient to succeed in the increasingly complex and evolving world Dewey saw unfolding in the early twentieth century.

Dewey emphasized social capital as something positive that lies beyond the individual, suggesting that it would become available when individuals connect to others in meaningful ways. Farr (2004) found that Dewey used the term a second time in 1909 when addressing the National Negro Conference in New York. Dewey encouraged enfranchised Americans to think about the disenfranchised in their midst (1909) and how within each race lies "all points of skill ... from the inferior individual to the superior individual." He went on to say that social capital is lost to any society that does not furnish the environment and education necessary to bring out the best in any individual. Here, too, the reference to social capital is not defined but is suggestive of a valuable resource that does not reside with the individual but emerges from interaction among individuals. One other known reference from Dewey does nothing to further enlighten what he meant when using the term. In the revised edition of The School and Society $(1915,104)$ Dewey repeats verbatim his ideas about social capital made in 1900.

The first detailed description of social capital comes from L. J. Hanifan, a West Virginia school superintendent and contemporary of Dewey's who wrote about social capital as "substances [that] count for most in the daily lives of people: namely good will, fellowship, sympathy, and social intercourse among the individuals and families who make up a social unit." Like Dewey and Tocqueville, Hanifan concluded that the individual "is helpless socially, if left to himself" $(1916,79)$. According to Hanifan, the individual who comes into contact with his neighbor, and the neighbor with other neighbors, will accumulate social capital and the community will "benefit by the cooperation of all its parts" (79). Farr (2004) argues, and rightfully so, that Hanifan would have been familiar with Dewey's work and may have employed the term social capital after reading either The Elementary School Record or the revised edition of The School and Society. 
Hanifan was the last one known to write about social capital for nearly a half century. As of his writing, the concept had taken on two forms, one rooted in the ideas of the political economists and one rooted in Dewey's ideas pertaining to education and associational life. References to the concept appear in Jane Jacobs's work on urban environments (1961) and in Glenn Loury's work on racial inequalities (1977), but neither scholar discussed it at length. The next scholar to write in any detail about social capital was Pierre Bourdieu (1980; 1983; 1986), whose ideas are argued to be the most theoretically refined (Portes 1998). His work and James Coleman's work (1987; 1987; Coleman and Hoffer 1987; 1988), which are discussed in more detail below, mark the beginning of what might be called the modern conception of social capital. The dialog that continues to this day began with them.

An important connection between early and modern references to social capital is a common belief that it is an essential element in the advancement of individuals. Even the use by political economists resonates of something emerging from cooperation. At least as far back as Tocqueville, observers of the changing American society recognized how social relations would play an important role in the achievement of desired outcomes. Images of the archetypal American as a rugged individual who can overcome adversity alone did not come from these early observers. Accomplishing desired outcomes in the changing world increasingly meant working more closely with others, and social capital was one means of conceptualizing how relations among individuals were critical to success in many senses of the word.

\section{Social Capital: The Concept Matures}

Bourdieu and Coleman have done the most to frame the conceptual debate over social capital. Despite claims that the concept suffers from "acute definitional fuzziness" (Foley and Edwards 1999) or from lack of a common definition (Fukuyama 2002), there is overlap in their thinking about the value of associational life. Coleman viewed social capital as a multidimensional concept, and in one of those dimensions (networks) he and Bourdieu agree. The source of much debate and criticism regarding Coleman's work has come from his inclusion of norms as a second dimension.

Bourdieu's ideas appeared first in Europe $(1980 ; 1983)$ and later in the United States (1986) in translation. To him, social capital is "the aggregate of the actual or potential resources which are linked to possession of a durable network of more or less institutionalized relationships of mutual acquaintance and recognition-or in other words, to membership in a group" (248). He argues that group membership provides those in the group with a "credential" that acts as a sort of credit upon which they can draw. To assess one's volume of available social capital one must consider two things: the size of the network and the capital available from others in the group. Larger networks of individuals with access to larger stockpiles of capital (Bourdieu wrote specifically of economic and cultural capital) have more to offer than do smaller networks of individuals of more limited means. Social capital is 
distinct from other forms of capital, and its accumulation, according to Bourdieu, exerts a multiplier effect for the individual engaged in the network, making available to him more than what he alone may possess.

The relationships that are the basis of a network come into being and are maintained in one of two ways, according to Bourdieu. First, they can be the result of some initial and then ongoing material or symbolic exchange. Second, they can be socially instituted and guaranteed by the application of a common name, such as that of a family, a class, a tribe, a school, a party or an organization (Bourdieu 1986). Relationships are not a natural or social given but are the result of time and energy invested, consciously or unconsciously, toward the generation or reproduction of relationships that are "directly usable in the long or short term" (249). In either case, it is after the formation and solidification of the group that social capital becomes available for use as a resource. Bourdieu's ideas about social capital appeared about the same time that Coleman would have been preparing for print several publications that incorporated the idea of social capital (1987; 1987; Coleman and Hoffer 1987). It is not clear that Coleman was aware of Bourdieu's work in Europe or the United States.

Like Bourdieu, Coleman (Coleman and Hoffer 1987) viewed social capital as emerging from social relations between persons. He defined social capital initially as norms (1987), then as norms, social networks, and relationships (1987), and shortly thereafter by its function (1988): "It is not a single entity but a variety of different entities, with two elements in common: they all consist of some aspect of social structures, and they facilitate certain actions of actors-whether persons or corporate actors-within the structure. Like other forms of capital, social capital is productive, making possible the achievement of certain ends that in its absence would not be possible" $(1988$, S98). Coleman goes on to identify specifically how social relations among members of a network or group can constitute useful capital resources when they produce obligations, expectations, trust, information channels, and norms as effective sanctions, all of which he argues can facilitate action among individuals. Coleman views social capital as analogous to physical and human capital: "Just as physical capital is created by making changes in materials so as to form tools that facilitate production, human capital is created by changing persons so as to give them skills and capabilities that make them able to act in new ways. Social capital, in turn, is created when the relations among persons change in ways that facilitate action" $(1990,304)$.

Bourdieu and Coleman theorized somewhat differently about social capital, but the core element common to each is the potential for associational life inside and outside the family to aggregate into a valuable resource, and this also was clearly an important idea to Dewey. Though he never elaborated on the concept of social capital in detail, Dewey wrote about education and networks in ways that reveal a common understanding with those of Bourdieu and Coleman. Dewey wrote about "the network of social activities that bind people together" (MW 8: 362) and about 
how "society means association; coming together in joint intercourse and action for the better realization of any form of experience which is augmented and confirmed by being shared" (MW 12: 196). When Dewey linked the importance of reading, writing and arithmetic to social capital (1900) he was acknowledging their importance in making valuable connections within and beyond one's own family or group.

The idea that associational life produces an important resource for achieving desired outcomes is a powerful one. Elinor Ostrom (2000) argued that social capital is human made, just as are physical and human capital, and that all three of these forms grow out of transaction and transformation activities that require the consumption of time and energy. Individuals are building capital when they spend time and effort taking a set of physical inputs and transforming them into another set that may then be used in further transformation activities or may be consumed. Transaction activity complements transformation activity, with the former referring to the relationships among the individuals involved in the process and the latter referring to the process itself. In somewhat similar terms, Dewey (1916) described education as a process of transmission, whereby parents or more senior members of a society interact with younger member and as a result transmit from one generation to the next what is necessary to achieve desired ends.

In the context of education, an early example of social capital formation and use comes from Hanifan, whose view of people and social interaction, as well as a belief in the school as the center of the community, prompted him to initiate a community survey, an agricultural fair, the development of a community history, and other activities that brought 2,180 residents in a thirty-three-square-mile area in his community into more regular contact. Through these various activities, residents began meeting and engaging with other residents, with teachers and with principals in the fifteen schools of the community. Hanifan (1916) attributes the following outcomes to the increased social capital that grew out of these interactions: a 14 percent increase in student attendance, when compared to the previous year; the start of adult literacy classes; the start of a youth athletics league; the raising of money for school libraries; the raising of teacher salaries; and the passage of a bond levy for highway improvements.

Dewey's ideas and Hanifan's early example suggest a virtuous cycle operating in society whereby the basic skills of reading, writing, and arithmetic are necessary to access social capital and that social capital, in turn, helps to drive success. More recent empirical evidence suggests a link between social capital and higher student and school performance (Coleman and Hoffer 1987; Teachman, Paasch, and Carver 1997; Putnam 2000; Goddard 2003; John 2005), but questions remain about how the concept actually works. A decade ago Robert Putnam was among those to observe the relationship: "Why does the density of social connectedness in a state seem to have such a marked effect on how well its students perform in school? The honest answer is that we are not yet entirely sure" $(2000,301)$. Though he went on to offer answers to his own question, Putnam (2001) cautioned that much more work would be needed to test theories linking the two. 
The sections to follow seek to provide, in several steps, a theoretical answer to the question of why social capital may affect outcomes in education. First, the idea of community is considered to set up the discussion about how social capital can be argued to work differently across communities. Second, three dimensions of social capital are examined, one of which is networks and is the dimension upon which Bourdieu and Coleman were in agreement. The second two dimensions come from Coleman's ideas about social capital. Finally, drawing on the three dimensions of social capital, specific indicators and linkages are examined to explain how it is that social capital can work as a resource for educators seeking a specific outcome, such as increasing performance levels among students and in schools. These indicators also point toward ways in which educators can try to grow social capital within their schools and communities.

\section{Conceptions of Community}

Scholars have sought to distinguish between situations and settings where social capital is available or accessible as a resource and where it is not, suggesting that its presence or absence can lead to differential outcomes. Significant emphasis to date has been placed on the presence of associational life in communities and collective action. Given that this activity or condition is argued to exist within groups and communities, it seems reasonable to conceive of communities existing in one of two extreme forms, with most likely falling somewhere in between. At one extreme lies the anomic community, where individual or "privatistic" interests dominate, and at the other extreme the solidaristic community, where the interests of the whole are given great weight in the motivations and decision calculus of individual members.

The privatistic community is characterized by very low levels of social interaction between individual members of the community, very few associational or civil society groups, and an absence (on the part of individuals) of community identification, community concern (or solidarity), and community information and memory. Instead, individuals' collective identities are restricted to small and relatively exclusive groups, such as family and church, and individuals adopt individualistic or privatistic outlooks and values. The solidaristic community represents the opposite form, where connectedness and solidarity exists across families and exclusive groups.

Conceiving of the community in this form is reminiscent of the gemeinschaft and gesellschaft conceptualizations of the nineteenth-century sociologist Ferdinand Tonnies, who used the term gemeinschaft when describing the community in its allegedly original, "natural" form, where people voluntarily worked cooperatively for the greater good of all (1935). Tonnies contrasted gemeinschaft with gesellschaft, where the development of the individual and self-interest dominate man's thinking. The 1970s and 1980s debate between liberals and communitarians is a more recent example of similar ideas. In this case liberals argued in favor of preserving individual choice through resisting the efforts of external threats, such as the state. 
Communitarians, on the other hand, placed value on liberty but viewed excessive individualism as likely to bring about the fragmentation of communities (Terchek 1997). It is worth noting that in their study of social capital and Italian regional governance, Putnam, Leonardi, and Nanetti (1993) assembled communities along a similar continuum.

If this conception of community is accepted, then it can be argued, given what we know or think we know about social and political behavior, that those born into a privatistic or solidaristic community will pass along these ideas and this behavior to future generations. Dewey (1916) argued that society continues to exist in much the same way as biological life, which is through the process of transmission: "The transmission occurs by means of communication of habits of doing, thinking, and feeling from the older to the younger. Without this communication of ideals, hopes, expectations, standards, opinions, from those members of society who are passing out of the group life to those who are coming into it, social life could not survive" (3). Taken together, these ideas suggest that adopting an individualistic or privatistic outlook instead of a more community-oriented outlook is learned behavior, and presumably it can be altered. As Tonnies argued that communities can transform from gemeinschaft to gesellschaft, Dewey argued that society must by nature undergo a constant reweaving of its social fabric. What form the new fabric takes depends entirely on the work that has, or has not, been put into the process by members of the community, and the center of this reweaving, according to Dewey, is or should be the school.

Common conceptions of community lead many to think in terms of villages, towns, municipalities, suburbs, cities, or some other means of identifying an area in geographic terms. This is certainly one view, but Dewey believed that physical proximity was not the defining characteristic: "Men live in a community in virtue of the things which they have in common; and communication is the way in which they come to possess things in common. What they must have in common in order to form a community or society are aims, beliefs, aspirations, knowledge-a common understanding-like-mindedness as the sociologists say. Such things cannot be passed physically from one to another, like bricks" $(1916,4)$. What makes one community different from another, then, is not necessarily the observable spatial distinction but the less tangible differences of what its members commonly know and value.

Educators echo Dewey's sentiments when they talk about school communities and how different sets of residents from different neighborhoods, subdivisions, blocks or farms produce different social dynamics within schools even though they may not be all that far apart spatially or all that different in terms of demographic characteristics. In the same way that people who live on the same street come to interact (or not), parents with children in the same school come to interact (or not). Attendance rules based on geography are standard arrangements in public schools, and are the basis for determining what parents and students end up together in a school. It is the social relations among students, parents, staff, teachers and administrators, however, which truly define the school community. Some parents travel 
great distances to have their children attend a particular school because its aims, beliefs, aspirations, or knowledge agree with their own and because the transmission they desire for their children may not have been available at the school nearest their home. Dewey's conception of community is important because the continuum of communities described above-as composed of individuals who are either privatistic or solidarstic in their orientations-is likely to reproduce itself inside the school community.

What these views of community mean for the formation of capital in a community, particularly social capital, is important. Other forms of capital, such as human capital or economic capital, are useful to communities too, but they are more commonly thought to reside with the individual and, once accumulated, to become instruments of the individual. Social capital never takes on this trait, for it adheres within social structures and requires social relations and associational life to be of value as a resource. In a privatistic community, where individuals keep more to themselves, the network connections to which they are attached will be more narrow and likely to benefit only the select few with whom they associate. In a solidaristic community, where individuals associate more widely and care more about the broader community, the network benefits can be argued to be wider and available to benefit more individuals than just the select few.

In a school community characterized by a privatistic outlook, for example, parents would likely use their social connections to coordinate action to advance a program that would benefit their children. Athletic boosters in this community will likely want to see proceeds go toward new equipment, facilities, and uniforms to benefit the athletes. That the band members may also need new instruments or uniforms will be of lesser or no concern. Parents in the solidaristic community would likely use ties across groups for the advancement of the school as a whole. They would be less concerned about a single program and more interested in the advancement of all programs, making it more likely, for example, that athletic boosters would want to help fund some band expenses, given the contributions of the band to athletic events. Thinking about communities lying along a continuum of this kind is helpful for considering the dimensions of social capital and for considering how linkages between social capital and student and school performance might work.

\section{Networks, Norms, and Relationships: Three Dimensions of Social Capital}

The scholars discussed above agreed on the importance of associational life, from which the one thing of value known to emerge is networks. This was the basis of social capital for Bourdieu. Coleman did not view social capital so simply, however. He theorized that from social relations can also emerge norms and relationships that can be of great value in accomplishing goals, thus conceiving of social capital as a multidimensional construct. Bourdieu did not write about norms, but he did consider relationships and "long-lasting dispositions of the mind and body" (1986, 
243) to be important. The latter construct is treated separately from social capital and is included as part of his conceptualization of cultural capital. It is here where the conceptual debate produces a split among social capital scholars. No attempt is made in this article to resolve the difference. The overlapping interest in networks is explored, as well as Coleman's interest in norms and relationships.

Networks are connections among individuals within or across groups, and their importance has been discussed widely among sociologists (Granovetter 1973, 1983; Bourdieu 1986; Burt 1992; Lin 1999). Granovetter describes the connections individuals make within homogeneous groups as strong ties and those made across heterogeneous groups as weak ties. The same notion is captured by Putnam, who wrote about within-group connections as bonding social capital and across-group connections as bridging social capital (2000). To illustrate, one can think of connections within a large ethnic family or within a church as strong ties or bonding social capital. One can think of connections across groups, such as between a school PTA and a local Rotary or Elks Club, as a weak tie or bridging social capital. The latter connection is made by someone who is a member of both groups. Researchers assign value to both types of connections, although connections made across groups are viewed as more valuable because they provide access to a more diverse range of resources.

Another important distinguishing characteristic of networks is their density. Dense social networks are highly populated, and individuals embedded in dense networks gain advantages over their peers not in similar situations. Lin (1999) offers three reasons why networks are valuable. First, networks facilitate the flow of information, particularly when it comes to opportunities and choices. Second, social ties across networks (weak ties or bridging social capital) often carry influence over actors in positions to make strategic choices. And third, individuals entering a network with connections to additional networks are often seen as extending the existing network in valuable ways. Participation in a dense network provides greater potential for information flow, influence, and expanded access to others.

Bourdieu argued that dense networks can accumulate and can be transmitted across time and space, and that accumulation and transmission of capital is one reason why all outcomes in life are not equal. Individuals embedded in dense social networks have more resources at their disposal for achieving desired outcomes. Once established, those connections can be maintained and transmitted across time, further advantaging the individuals in those groups. Dewey's argument about the value of education to accessing social capital suggests that he understood this very idea. Without reading, writing, and arithmetic skills individuals would be locked out of certain groups that would, over time, lead them to fall behind and remain behind others more economically advanced.

Linking this dimension of social capital to the ideas of community discussed above, one can expect that in a privatistic community, where individuals keep more to themselves, network connections will be less dense and more of a strong tie or 
bonding nature. In a solidaristic community, where individuals associate more widely and are argued to care more about the broader community, the network connections will be denser and of a weak tie or bridging nature. The benefits to the school in the latter community will be greater access to resources that can be used to enhance performance. Just as Hanifan used those connections to decrease absenteeism among students, a principal might use similar connections to provide supplemental educational materials, such as science equipment, help to fund curriculum-enhancing fieldtrips, or identify guest speakers, mentors, or volunteers. The options for drawing on resources in the network will only be constrained by the size of the network and the resources made available within it by constituent members.

A school community characterized by a privatistic outlook would likely find parents more inclined to advance programs that will benefit their children even at the exclusion of others. Rather than helping to raise money for the school's general advancement, what may emerge is targeted fundraising, where parents help generate funds for science needs if their children will benefit most from science equipment. Parents in the solidaristic community who are embedded in dense and overlapping networks would be more inclined to focus on school needs in general, thinking about more than just the needs of the program in which their children are involved.

A second dimension of social capital is argued by Coleman to be norms, which emerge as a result of ongoing association among individuals. Norms are "expectations about action-one's own action, that of others, or both-which express what action is right or what action is wrong" (1987). Coleman illustrated the role of norms in social capital using as an example the diamond exchange network, within which valuable stones pass back and forth among sellers with relative ease and minimal risk. A norm of honest exchange results in lower transaction costs and facilitates business for everyone in the network by creating a larger supply of merchandise to show potential buyers. Individuals who respect the norm are permitted to remain and benefit from the arrangement. Anyone found shorting a bag of stones without compensation to the owner risks being sanctioned by the network, that is, being excluded from receiving future merchandise. Similarly, Putnam (1993) offers rotating credit associations as an example of the concept. Credit associations have been used around the world for centuries to concentrate financial capital into the hands of individuals who can then use it to further personal or business interests. In such an association individuals come together and agree to contribute some amount monthly to a pool, and each month the amount goes to a different member. Group formation and continuation are maintained by "strong norms and by dense networks of reciprocal engagement" (168). As with Coleman's example of the wholesale diamond industry, the sanctions associated with violating the norm are serious enough to prevent individuals from failing in their obligation to the group.

Norms are one explanation for why individuals may be solidaristic or privatistic in their outlooks. In the case of the privatistic individual, it is possible that a norm passed across generations urges one to consider outcomes only in the context 
of self. It may be too that some experience earlier in life led to an altered view of what action is right. Inside school communities, individuals who embrace norms emphasizing self above all others are likely to accept decisions or try to influence decisions that will direct resources toward programs that will most benefit their children, be it a particular athletic, artistic, or curricular interest. Although most probably do not wish others to suffer, their decision calculus may not consider the welfare of others.

In terms of Ostrom's ideas about transaction and transformation activities that produce capital, transaction activities at school would take the form of parents, teachers, administrators and students interacting on issues related to the children and school. Whether those interactions produce norms that support a productive learning environment-for example, norms supporting high performance, adherence to rules, respect for others-or norms of self-interest and disrespect will determine whether the social capital that is generated works to the advantage or disadvantage of the school. Not all norms are positive, just as all networks are not put to use toward positive ends.

The problem created by privatistic individuals in such a transactional environment is the impediment to larger-scale transformational activity that would lead to decisions where all would benefit. Individuals can splinter across issue areas or create factions, to borrow from James Madison's ideas in the Federalist Papers (Madison, Hamilton, and Jay 1787-88). This automatically pits individuals against one another in a competition for scarce resources. Some individuals, preferring to avoid the politics of it all, turn away from common interests and away from associational life, thereby reducing the potential for social capital.

Finally, the inclusion of relationships as a dimension of social capital is important because accounting for them as part of the social capital construct helps to explain variation in levels of social capital that emerge from networks and the extent to which norms are influential. Coleman (1987) includes relationships in his definition of social capital when writing about families and schools, but later focuses on networks and norms (Coleman 1988, 1990). Support for the importance of relationships comes from Ostrom (2000) and her connection of relationships to transaction activities that build capital. The outcomes of these transactions vary. In some instances individuals may part ways without producing any lasting connection, for example without forming any kind of relationship. In other cases, however, transactions may lead to the foundation and development of relationships which facilitate the transformation process, where coordinated action emerges and takes on the form of social capital.

Not all networks provide the same benefits, and not all norms are equally influential in the decision making of individuals. One way to think about the interrelationships of individuals is to think about them in the context of how Richard Fenno (1978) conceived of connections between United States Congressmen and their constituents back home. Fenno described Congressmen's constituent connec- 
tions as a series of concentric circles, where the most important people are at the center and the less important people are in one of several outer rings. Conceiving of norms and networks in a similar way is reasonable given that most individuals do not treat all people in a network and all expectations equally. Within networks there are some connections that are more valued or more productive than others. Likewise, there are some norms that individuals are more reluctant to violate or more willing to honor. It is the relationships among individuals that help to define what networks or what norms becomes most and least important.

In a privatistic community, the relationships emphasized most will be those that serve the family best, or those that are least likely to bring about bridging connections. The norms likely to be adhered to or passed along will be those that emphasize individual welfare, such as nearly unlimited rights to expression, ownership, and action. In a school community, the relationships that matter most will be those that deliver the most for one's child. Time well spent for a band parent, for example, will be time spent befriending the band leader or individuals influential with him (or her), rather than time spent at school furthering extra-curricular activities in general. That would be the responsibility of other parents.

The discussion of norms, networks, and relationships in the context of the privatistic community illuminates how actors in various settings may choose to behave. Even in the case of norms, there remains a choice to adhere to or to ignore expected behavior. In the paragraphs to follow a series of indicators are introduced that will be useful in transitioning from a purely theoretical discussion to an empirical one. Also included are the linkages that span the gap between the proposed indicators and outcomes.

\section{Social Capital: Indicators and Linkages}

Social capital is a social or group property that can exist when individuals come in contact with others. As should be clear from the previous discussion, it can neither exist without the individual nor be reduced to the individual. Like financial, human, and physical capital, social capital is an exploitable resource that must be developed if it is to accrue any benefits to the user (or to have any spillover benefits to others). Within communities, social capital refers to both individual and group variables. The presence of these variables to a greater degree positively influences levels of social capital, which in turn can facilitate formal and informal modes of collective action, as well as forms of spontaneous individual action. One outcome of collective and spontaneous individual action can be higher levels of student and school performance. In this sense social capital is a mediating variable that lies between the actions of individuals and outcomes.

This part of the article considers indicators of social capital that educators can use to assess levels of social capital within their own environments. Seven individual indicators and two group indicators are discussed in brief. Each is tied to one or more of the three dimensions of social capital already introduced. 
First, it is argued that individuals in high social capital communities have learned to be more socially cooperative. This is not to say that individuals do not possess personal interests; it is certain that they do, but those interests do not prevent them from working with others toward a common purpose. When action is required for the benefit of the community, socially cooperative individuals are likely to participate in the process. One explanation for such behavior is that they may have acquired this trait through transgenerational norms, through the efforts of cooperatively minded individuals to establish such a norm, or through participation in network activity. Recent efforts to introduce service learning opportunities at elementary, secondary, and postsecondary educations levels are examples of community-minded individuals seeking to establish, or re-establish, norms of social cooperation.

The second and third individual indicators can best be discussed together. Where individuals take an interest in and have knowledge of the community and its issues, there is likely to be a norm reinforcing such behavior and active networks facilitating the spread of knowledge. Interest in community can be shown in a variety of ways, from keeping current on events through media to attending meetings. The outcome of this interest can be increased knowledge of the issues facing one's community. Knowledge of the community and its issues can come from not only this behavior but from participation in group activity, be it religious, civic, or private in nature. Before individuals can come together to solve problems, someone or some group must understand the issues that need resolving or be seeking to understand them. Recall how Hanifan, the rural West Virginia school superintendent, used a community survey and the development of a community history to attempt to draw people together. It was their interest in the community, one can argue, that brought them out in the first place. Once involved, the knowledge they acquired of the community's situation provided the basis for action. Individuals who take an interest in and seek knowledge about their community may be following the example set by a family member or parent, or they may be responding to civics education lessons from grade school. When this behavior is exhibited, social capital is argued to be higher and the likelihood of collective action or spontaneous individual action is greater.

Fourth, individuals that genuinely care about the community and the individuals in it are more likely to engage in community-enhancing behavior. These feelings of solidarity are an important distinction between solidaristic and privatistic communities. Solidarity and the feelings associated with it act to bind individuals together. In Hanifan's story, interest and knowledge were critical, but so too was caring for fellow community members. If a meeting is called at school about safety or drug use, the interested parent will come seeking to understand the problem, but he will also come out of, at a minimum, a concern for his child or a concern for all of the community's children. Strong feelings of genuine concern are one reason that communities are likely to provide services to those who they believe are un- 
able or incapable of caring or providing for themselves. In the school community, norms of solidarity help to explain why additional resources are applied toward the education of needy children, why equality in expenditures is downplayed in favor of equitable distribution. The desire to see students overcome barriers to learning outweighs the desire to keep resources to oneself or to preserve resources for one's own child. Such action is argued to be the result of norms prohibiting one from turning his back on a neighbor.

Fifth, it is argued that individuals in high social capital communities are more likely to identify with the community and to view this identity favorably. These individuals feel as though they are a part of something larger than just themselves, and they hold this feeling in high regard. All communities have individuals who do not feel accepted, who do not feel that they or their views are welcome. The high social capital community is likely to have fewer of these individuals, as inclusiveness and acceptance are more important than dominance of a singular view. In the school community, lack of acceptance can lead students to withdraw and even to act out against the established community. Feelings of positive identification will lead them to participate in existing networks and to build and maintain relationships with other students, teachers, and administrators. Students who identify positively with the community are more likely to feel accepted and to engage in the school community.

Sixth, individuals in solidaristic communities will be more inclined to trust others in their community. Trust is a much debated concept. Scholars question whether people come to trust others because they interact with them or whether they interact with others because they are predisposed to trust. Trust in a solidaristic community is likely to exist in part because of norms that predispose individuals to trust others in their community and in part because of network experiences that expose them to individuals in the community and encourage them to trust. The two, being predisposed to norms of trust and participating in network experiences, are a virtuous cycle that cannot be disentangled easily.

In the school community, students who trust their teachers, and teachers who trust their principals are more likely to confide in others on issues that may be affecting their productivity and to work with others on issues affecting the school. In both cases, resolution of the problems is more likely. One way of conceptualizing trust is to think of it as the mutual expectations and obligations that participating parties, that is, students, parents, teachers, and principals, expect of one another in the school setting (Bryk and Schneider 2002): "For example, parents expect that teachers will take the necessary actions to help their child learn to read. Teachers feel obligated to work in a professionally appropriate manner and are willing to commit extra effort, if necessary, in seeking to respond to the parents' expectations. Parents in turn are obligated to make sure that students attend school regularly and, more generally, to support the teachers' efforts at home" (20-21). Each party trusts that the others will do their part, and any lapse in obligation reduces 
the quality of the relationship among the constituent parties, creating disharmony and problems that can impede performance. When synchrony exists among the participating parties, schools are argued to work well as organizations. Bryk and Schneider are among many (Kramer, Brewer, and Hanna 1996; Tschannen-Moran 2004; Bies and Tripp 2004) to emphasize the importance of trust in the school setting or in organizations generally.

And, finally, it is argued that in a high social capital community individuals are more willing to belong to and participate in community groups or associations. Participation comes from individuals with a shared interest in something, which could be the community itself or it could be a hobby, a trade, or a youth group of some kind. Neighborhood watch groups are common in certain parts of the country. Once together for a common purpose, such as preventing crime, these groups can be used for other purposes, such as helping to locate jobs or good repairmen or to learn about what is happening at the neighborhood school. Garden clubs, religious organizations, scouting dens or chapters, car clubs, and organizations like these have brought individuals within communities together for decades. In the school community, the most common organization is the PTA or PTO at the elementary and middle schools and the booster clubs at high schools. Active associations are evidence of viable networks and active relationships in communities. They may also be evidence of community norms that encourage such participation. Whether these connections are of the bridging or bonding type has to do with the type of relationship that exists among the individuals involved.

Moving beyond individual indicators, it can be argued that there are at least two community-level indicators of social capital. First, social capital can be said to be high at the community level when the number and variety of associational groups in the community is high and, second, when community-wide social networks are dense and overlapping (a function of high levels of associational activity and the number and variety of associational groups). Large numbers of associations in a community are indicative of a community where individuals are active beyond home and family life. This activity is even more valuable when membership levels are high (dense) and when individuals belong to multiple groups or associations (overlapping), as when the gentleman in the garden club is also a member of the Elk's or maybe even a third group. A community environment such as this provides those individuals possessing varied interests with a means of connecting to others who share their interests. The benefits of this are many: individuals come to know more people, at least informally; the transfer of knowledge is facilitated; and individuals are more likely to positively identify with the community since they are able to find and interact with others whose interests and values are similar.

Where these individual and group indicators of social capital are found in higher levels, collective action is more likely and unorganized, essentially spontaneous, individual initiatives and efforts that serve the community are also more likely. These two actions are the linkages that tie social capital to higher levels of school 
performance. Social capital itself does not guarantee collective action or spontaneous individual action, but it does make their emergence more likely.

\section{Social Capital Linkages: Collective Action and Spontaneous Individual Action}

Collective action is often written or talked about in the context of collective action problems. ${ }^{1}$ When a problem in a community needs addressing, and the actions of many are required to solve the problem, it often happens that no action occurs. Scholars have long been interested in why this occurs. The commonly accepted answer is the incentive for individuals to "free ride." They know the problem exists and that many, but not all, will have to act for it to be resolved; so, they wait for others to act. The problem arises when everyone ends up waiting and no one ends up acting. Social capital facilitates collective action because when levels are high, individuals are by definition more interested, more knowledgeable, and more concerned about their community. They are networked with others through their involvement in associations and groups; so, it is more likely that they will have information about problems and that they will come together to act since they are already together for other purposes. Recall how the citizens Hanifan brought together for one purpose became involved in other community-related projects after they had come together.

Social capital can also facilitate spontaneous individual action for similar reasons. An individual who identifies with and cares about the community, who is interested in a certain problem and possesses knowledge of the problem is more likely to attempt a solution. In the school community, this is the parent who finds out the the school science lab needs new equipment and decides to write to companies or foundations and to visit local bank presidents or civic club leaders in an effort to find someone willing to donate the needed equipment. When social capital is high, the prospects of action and success are greater.

Social capital's facilitation of collective action can lead to the emergence in schools of beneficial behaviors and activities. For example, one may find increased ownership in the state of the community and, as a result, greater concern for the conditions of the community. This may mean that more will be done to deter crime in some areas by upgrading lights, funding increased patrols, or initiating neighborhood watch groups. In the school community, this may lead individuals to push the school district leadership for fund-raisers or a bond campaign to upgrade facilities. It may also lead to school improvement days, where parents, employees, and friends of the school spend time cleaning up the landscape, installing playground equipment or painting classrooms and hallways.

One may also find increased ownership in the outcomes of the community. Greater concern in this context may emerge in the broader community in individuals volunteering for victim advocate programs through the court system or volunteering to answer phone calls on a crisis hotline for teens or victims of do- 
mestic abuse. In the school community, concern about outcomes can lead to the creation of programs to connect men and women from the business community to troubled youths in school, often known as mentoring programs, or to the creation of after-school programs and tutoring involving senior citizens or college students.

Social capital's facilitation of collective action can also lead to the enabling of networks that tie individuals together (Note the virtuous cycle here: participation generates social capital and social capital generates participation). Once collective action is stimulated and groups of individuals are brought together for a single purpose, the network created can be used to fulfill the immediately desired outcome, but it can also be put to use and expanded for other purposes throughout the duration of the network's existence. This is what is referred to as fungibility. For example, The March of Dimes, a nonprofit organization, created a nationwide network to raise money to fight polio. When a cure was found, and polio was no longer a threat to society, the established network of individuals turned its attention to fighting birth defects, a mission it still pursues today. In the school community, parents who come together through fund-raisers, PTA, PTO, or booster clubs may connect outside of that setting for other activities that are enhancing to the schools, such as involvement in the steering committee to run a district-wide bond campaign or an action committee working on part of the school's strategic plan.

As in the case of collective action, social capital's facilitation of spontaneous individual initiatives can lead to the emergence of behaviors that can be said to be beneficial to the community. For example, individuals may be compelled to communicate their concern for and pride in the community to others, to encourage others to be community-minded like them, to informally sanction those who are not community-minded, and to engage in behaviors such as not littering or voting in favor of community-enhancing goods like school bonds. In the school community, this behavior emerges in alumni or parents who are often strong supporters of the school. Urban high schools that have undergone significant demographic changes over the years will often have alumni from various generations and backgrounds who remain strong advocates and spokespersons for the school, who encourage others to view the school as they do, and who are quick to support initiatives that may enhance the school. When their connections in the workplace or community may benefit the school, they are willing to make the necessary contacts. Parents and alumni in this environment will be quick to correct others who do not give the school its due when talking about it publicly or will press others to get behind a bond campaign that will improve conditions at the school for children.

The discussion of collective and individual action clearly focuses on how social capital can be a positive resource for schools. Hanifan wrote about the positive achievements of the group he assembled to write a community history. It is certainly possible that such a group, once formed, could go on to pursue a reform agenda aimed at removing a school board member, a superintendent or a principal; it could pursue controversial topics such as science teaching and evolution. There 
is no denying that social capital, once generated, could be purposefully used toward ends not all citizens believe to be good. The choice to emphasize the positive potential of social capital, however, is predicated on the belief that citizens want to see schools, and the children in them, succeed. Citizens may have very different ideas about what success means, what is wrong in any given school setting, and how best to achieve success, but it is hard to imagine the majority of citizens in any community wanting to see its schools, and its children, fail. Resolving differences, even the most controversial, is an important though sometimes frustrating part of serving communities as educators do.

\section{Discussion and Conclusion}

Social capital as a concept has evolved considerably since Dewey's first use, but in drawing this article toward closure it seems prudent to reflect more generally on social capital, Deweyan notions of community and challenges educators face in the current education policy environment. Two of Dewey's ideas seem particularly interesting to consider in this light. The first is that communities are not communities by nature of geography but by shared "aims, beliefs, aspirations, knowledgea common understanding" $(1916,4)$ and the second is that schools belong at the center of communities, facilitating ongoing social interaction and the continuous reweaving of the social fabric. Both ideas are taken in turn and considered against the backdrop of the current education policy environment.

In describing communities as groups of individuals possessing a common understanding, Dewey was in some ways describing what Coleman (and Putnam after him) would later suggest are indicators of a high social capital environment. Dewey understood as well as Coleman and Putnam that outcomes desired by individuals living in general proximity to one another, though not always identical, are dependent upon some shared level of understanding and agreement. Whether expressed as an absence of community or as low levels of social capital, there is overlap in thinking and emphasis. Spatial location of residence does not guarantee community to Dewey or social capital to Coleman and Putnam. Connection to one another, either spatially or via some form of technology, is only a necessary precondition of community or social capital. The choices individuals make about their interactions with others will determine whether community or social capital emerges.

In a study of high school student performance, Coleman (1987) observed that students at Catholic schools outperformed their peers at both public high schools and private but non-Catholic high schools. His theoretical explanation for this observed variation includes social capital, but in explaining what he meant Coleman tapped into the very notion of the Deweyan community. Coleman argued that parents and children at Catholic schools were more tightly connected to one another, that they shared values and beliefs important to the education process, and that they were more effective at transmitting these values and beliefs across generations. The more formal name of this interactive process between parents and children he 
called intergenerational closure, something he also describes in later publications (Coleman 1988, 1990). Unlike traditional public high schools, private schools (including Catholic schools) are not likely to be as strictly bound by geography in the determination of their student and family population. As population becomes less dense the travel times to and from school certainly play a deciding role in determining any school's student population, but the decision to attend a private school can be less of a matter of simple geography in many instances because of the absence of formal attendance boundaries imposed by a public governing authority.

The current education policy environment in the United States reflects an ongoing struggle over geographic assignment to schools. The charter school and voucher movements are probably the most visible examples of reform efforts in this area. Advocates (Moe 2001; Chubb and Moe 1988) draw on arguments by economist Milton Friedman (1955; 1962), who suggested that marketlike competition among schools would lead to greater efficiency and effectiveness. When students are geographically assigned to a school no choice is afforded the parents, which advocates argue creates an undesirable monopolistic environment that allows unsuccessful schools to exist in perpetuity. Choice does not have to come in the form of vouchers and charter schools, however. Some school districts are experimenting with choice within their own boundaries and among their own schools.

Regardless of one's perspective on Friedman's arguments, an important side effect of geographically assigning students is that parents cannot choose a school community that reflects their values and beliefs. If the importance of community as expressed by Dewey, Coleman, and Putnam is correct, then the absence of choice in some form is significant. Parents who find their children assigned to a school that does not reflect their values and beliefs are left with several undesirable options. They can accept the values and beliefs of the school even though they do not share them. They can sell their home and move (something increasingly difficult to do in the current housing market). Or, they can engage the school administration and other parents in dialog designed to alter what they find unacceptable in the community. This last option requires parents to step into a political process that may lead to confrontation, something not all parents are likely to feel equally comfortable doing and something most school administrators would likely prefer to avoid. A school administrator, like the parent, must engage others when shared beliefs and values are absent or where they are present but are counterproductive to the overall mission of raising achievement. The challenge of negotiating this terrain seems more likely to occur in the public school environment where geographic assignment lumps together individuals in a school setting who may be more diverse in terms of their values and beliefs.

Dewey's idea about schools serving as centers of communities also is worthy of reflection in the context of the current policy environment. Schools today remain primary hubs of activity. They bring together regularly people of different races, ethnicities, religions and backgrounds for a common purpose. The percentage of 
people in an area overall who come into regular contact with a school as part of its primary mission has changed considerably over the past several decades, however. This change poses important challenges for educators if schools are going to be places where the continuous reweaving of a community's social fabric takes place and social capital is generated.

Two statistics from a report of demographic trends in America by the U.S. Census Bureau (Hobbs and Stoops 2002) enlighten the challenge of making schools the center of communities. The Census Bureau divides households in America into two types: family households and nonfamily households. The difference between the two is whether individuals in the household are related by birth, marriage, or adoption. Among family households in 1960, 56.9 percent had children living at home under the age of 18 . By 2000 that number had dropped to 48.2 percent and the most recent estimate for 2006-2008 shows that number dropping further to 46.6 percent. ${ }^{2}$ Also telling about demographic changes among households is the rise in the percentage occupied by one individual. In 1960 only 13.3 percent of households were one-member households. By 2000 that number had climbed to 25.8 percent and the most recent estimate for 2006-2008 shows that number up further to 27.5 percent. Increasingly among households in American communities, families are less likely to have children in school and more are likely to be populated by individuals living alone.

The nature of schooling will always bring some individuals, particularly parents, into close contact with one another as they volunteer or seek to support a school in fund-raising or in other collaborative activities. One challenge facing educators is to figure out how to get into the schools members of households without a natural connection through children. Some debates in the current policy environment center on the overall cost of public education and the quality of outputs. With many school districts dependent on public approval of bond levies for either operations revenue, capital improvement revenue or both, developing community or growing social capital among individuals without children in school may be an important activity for preserving current offerings. Absent any contact with the schools, residents may rely solely on information from accountability reporting mechanisms to assess school quality, and this may be problematic.

Several school and district programs to emerge over the past several decades are likely to be helping schools make contact with this outside crowd. The emergence of mentoring programs served two important functions. First, mentoring introduced students without positive role models to someone willing and capable of filling that gap in the child's life. Perhaps of equal importance was that mentoring programs brought into schools individuals who may have had no other reason be there. Mentoring created an opportunity for individuals living or working in proximity to a school to see the challenges faced by teachers and administrators. It also may have helped to grow community or build social capital. Adopt-a-school and business partnership programs have served a similar function, as have pro- 
grams designed to open school libraries, recreation facilities and meeting facilities to the general public during non-school hours.

The current policy debate focuses intently on holding schools and their employees accountable for student achievement. Disputes about the appropriate measures for determining these outcomes remain unresolved, as do questions about the level of funding required to implement successfully the current accountability system as adopted in the form of the No Child Left Behind Act. The theoretical ideas presented here are meant to suggest that success in education may require resources beyond those that are normally thought to be important. Dewey recognized the importance of the social dynamic in communities as they were changing at the turn of the twentieth century, and late twentieth-century and early twenty-first-century scholarship is building on some of the same ideas Dewey advanced.

This article sought to frame the social capital debate in the context of schools for the benefit of educators. Some students and schools do perform better than others and the exact reasons why are often difficult to identify, particularly when it appears that resources across schools are equal. One answer may be variations in levels of social capital. Discussion about social capital should continue, and as it does more attention needs to be given to how it works in communities and schools, and how administrators, teachers, parents and students can advance its growth. Additionally, more empirical work is needed to help assess and advance current theory.

\section{Notes}

1. See for example, (Olson 1965) or (Hardin 1968).

2. This estimate is based on the United States Census Bureau's American Community Survey. According to the 2006-2008 ACS three-year estimates, there were 112,386,298 households in America and of those 38,517,706 had at least one person under the age of 18.

\section{References}

Bellamy, Edward. 1897. Equality. New York: D. Appleton.

Bies, Robert J., and Thomas M. Tripp. 2004. "Beyond Distrust: 'Getting Even' and the Need for Revenge." In Trust in Organizations, edited by Roderick M. Kramer and Tom R. Tyler, 246-60. Thousand Oaks, CA: Sage.

Bourdieu, Pierre. 1980. "Le capital social: notes pro-visoires." Actes Rech. Sci. Soc. 31: 2-3.

. 1983. “Okonomisches Kapital, Kulturelles Kapital, Soziales Kapital.” In Soziale Ungleichheiten (Sociale Welt, Sonderheft 2), edited by Reinhard Kreckel, 183-98. Goettingen: Otto Schartz.

. "The Forms of Capital." 1986. In Handbook of Theory and Research for the Sociology of Education, edited by John G. Richardson, 241-58. New York: Greenwood. 
Bryk, Anthony S., and Barbara Schneider. 2002. Trust in Schools: A Core Resource for Improvement. Edited by D. L. Anderton, D. Clawson, N. Gerstel, J. Misra, R. Stokes and R. Zussman. Rose Series in Sociology. New York: Russell Sage Foundation.

Burt, Ronald S. 1992. Structural Holes: The Social Structure of Competition. Cambridge, MA: Harvard University Press.

Chubb, John E., and Terry M. Moe. 1988. "Politics, Markets and the Organization of Schools." American Political Science Review 82, no. 4:1065-87.

Clark, John Bates. 1885. The Philosophy of Wealth. Boston: Ginn.

Coleman, James S. 1987. "Families and Schools." Educational Researcher 16, no. 6:32-38.

. Norms as Social Capital. In Economic Imperialism: The Economic Approach Applied Outside the Field of Economics, edited by Gerard Radnitzky and Peter Bernholz, 133-55. New York: Paragon House.

. 1988. "Sociological Analysis of Economic Institutions: Social Capital in the Creation of Human Capital.” American Journal of Sociology. 94 (Supplement: Organizations and Institutions: Sociological and Economic Approaches to the Analysis of Social Structure): S95-S120.

. 1990. Foundations of Social Theory. Cambridge, Mass.: The Belknap Press of Harvard University Press.

Coleman, James S., and Thomas Hoffer. 1987. Public and Private High Schools: The Impact of Communities. New York: Basic Books.

De Souza Briggs, Xavier. 1997. "Social Capital and the Cities: Advice to Change Agents." National Civic Review 86, no. 2:111-17.

Dewey, John. 1900. “The Psychology of the Elementary Curriculum.” In The Elementary School Record, edited by John Dewey, 1:219-32. Chicago: University of Chicago Press. . 1909. Address. Paper read at National Negro Conference, New York. . 1915. The School and Society. Chicago: University of Chicago Press. . 1916. Democracy and Education. New York: Macmillan Company. .1976-83. Middle Works, 1899-1924. Edited by Jo Ann Boydston. Carbondale: Southern Illinois University Press.

Farr, James. 2004. “Social Capital: A Conceptual History”. Political Theory 32, no. 1: 6-33.

Fenno, Richard F. 1978. Home Style: House Members in Their Districts. Boston: Little Brown.

Foley, Michael W., and Bob Edwards. 1999. "Is It Time to Disinvest in Social Capital?" Journal of Public Policy 19, no. 2: 141-73.

Friedman, Milton. 1955. “The Role of Government in Education.” In Economics and the Public Interest, edited by Robert A. Solo, 123-44. New Brunswick, N.J.: Rutgers University Press. 1962. Capitalism and Freedom. Chicago: University of Chicago Press. 
Fukuyama, Francis. 2002. "Social Capital and Development: The Coming Agenda." SAIS Review 22, no. 1:23-37.

Goddard, Roger D. 2003. "Relational Networks, Social Trust, and Norms: A Social Capital Perspective on Students' Chances of Academic Success." Education Evaluation and Policy Analysis 25, no. 1:59-74.

Granovetter, Mark. 1973. “The Strength of Weak Ties.” American Journal of Sociology 78, no. 6: $1360-80$.

. 1983. "The Strength of Weak Ties: A Network Theory Revisited." Sociological Theory 1: 201-33.

Hanifan, Lyda Judson. 1916. “The Rural School Community Center." Annals of the American Academy of Political and Social Science 67: 130-38.

Hardin, Garrett. 1968. “The Tragedy of the Commons." Science 162: 1243-48.

Hobbs, Frank, and Nicole Stoops. 2002. U.S. Census Bureau, Census 2000 Special Reports, Series CENSR-4, Demographic Trends in the Twentieth Century. Washington, D.C.: U.S. Government Printing Office.

Jacobs, Jane. 1961. The Death and Life of Great American Cities. New York: Random House.

John, Peter. 2005. “The Contribution of Volunteering, Trust, and Networks to Educational Performance." The Policy Studies Journal 33, no. 4:635-56.

Kramer, Roderick M., Marilynn B. Brewer, and Benjamin A. Hanna. 1996. "Collective Trust and Collective Action: The Decision to Trust as a Social Decision." In Trust in Organizations, edited by Roderick M. Kramer and Tom R. Tyler, 357-88. Thousand Oaks, CA: Sage.

Lin, Nan. 1999. "Building a Network Theory of Social Capital." Connections 22, no. $1: 28-51$.

Loury, Glenn C. 1977. “A Dynamic Theory of Racial Income Differences.” In Women, Minorities, and Employment Discrimination, edited by Phyllis A. Wallace and Annette M. LeMond, 153-86. Lexington, MA: D. C. Heath.

Madison, James, Alexander Hamilton, and John Jay. 2003. "No. 10: The Union as a Safeguard against Domestic Faction and Insurrection." In The Federalist: With Letters of Brutus, 535-36. Cambridge: Cambridge University Press.

Marshall, Alfred. 1890. Principles of Economics ( $9^{\text {th }}$ ed.). Edited by C. W. Guillebaud. London: Macmillan, 1961.

Marx, Karl. 1985. "Instructions for the Delegates of the Provisional General Council: The Different Questions.” In Marx-Engels Collected Works, 20: 188-90. New York: International Publishers.

Moe, Terry M. 2001. Schools, Vouchers, and the American Public. Washington, D.C.: Brookings Institution Press.

Olson, Mancur. 1965. The Logic of Collective Action: Public Goods and the Theory of Groups. Cambridge, MA: Harvard University Press.

Ostrom, Elinor. 2000. “Social Capital: A Fad or a Fundamental Concept?” In Social Capital: A Multifaceted Approach, edited by Partha Dasgupta and Ismail Serageldin, 172-214. Washington, DC: The World Bank. 
Portes, Alejandro. 1998. "Social Capital: Its Origins and Applications in Modern Sociology." Annual Review of Sociology 24: 1-24.

Putnam, Robert D. 2000. Bowling Alone: The Collapse and Revival of American Community. New York: Simon \& Schuster. . 2001. "Community-Based Social Capital and Educational Performance." In Making Good Citizens: Education and Civil Society, edited by Diane Ravitch and Joseph P. Viteritti, 58-95. New Haven, CT: Yale University Press.

Putnam, Robert D., Robert Leonardi, and Raffaella Nanetti. 1993. Making Democracy Work: Civic Traditions in Modern Italy. Princeton, NJ: Princeton University Press.

Sidgwick, Henry. 1883. The Principles of Political Economy. London: Macmillan. Teachman, Jay D., Kathleen Paasch, and Karen Carver. 1997. "Social Capital and the Generation of Human Capital." Social Forces 75, no. 4: 1343-59.

Terchek, Ronald J. 1997. Republican Paradoxes and Liberal Anxieties: Retrieving Neglected Fragments of Political Theory. Lanham, MD: Rowman \& Littlefield Publishers.

Tocqueville, Alexis de. 1840. Democracy in America. Edited by P. Bradley (Vol. 2). New York: Alfred A. Knopf, 1945.

Tonnies, Ferdinand. 1935. Fundamental Concepts of Sociology (8th ed.). American Sociology Series. New York: American Book Company.

Tschannen-Moran, Megan. 2004. Trust Matters: Leadership for Successful Schools. San Francisco, CA: Jossey-Bass.

Woolcock, Michael. 1998. "Social Capital and Economic Development: Toward a Theoretical Synthesis and Policy Framework." Theory and Society 27, no. 2: 151-208.

Gregory K. Plagens is an assistant professor in the Political Science Department at Eastern Michigan University.

E-mail: gkp4@uakron.edu 